\title{
The Blood Pressure Response during Graded Exercise Test in Obese Adults
}

\author{
Kyung-A Shin ${ }^{\dagger}$ \\ Department of Clinical Laboratory Science, Shinsung University, Chungnam 31801, Korea
}

\begin{abstract}
Obesity has been directly associated with the development of hypertension and cardiovascular disease. The purpose of this study was to investigate the blood pressure response during graded exercise test in obese adults. 189 subjects (age: 47.96 \pm 10.23 ) were assigned to two groups: non-obese group ( $\mathrm{N}=105$, BMI: $22.05 \pm 1.57$, waist circumference: 76.90 \pm 6.17$)$ and obese group ( $\mathrm{N}=84$, BMI: $26.96 \pm 2.51$, waist circumference: $88.29 \pm 6.41)$. The subjects underwent health screening and exercise treadmill test from January 2012 to December 2014. Graded exercise test was performed according to the Bruce protocol. Exercise duration $(P=0.046)$ and METs $(P=0.015)$ were significantly lower in obese group than non-obese group. There was no difference in the rate of change in blood pressure response between obese group and non-obese group during exercise, and the recovery rate of systolic blood pressure was delayed in the obese group compared to non-obese group in the first recovery period $(P=0.020)$. The significant factors of increasing rate of change in maximum systolic blood pressure was waist $(P=0.046)$ and hip circumference $(P=0.008)$. In conclusion, these results demonstrate that, for hypertension prevention in obese adults, waist and hip circumference levels should be managed within normal range.
\end{abstract}

Key Words: Blood pressure, Obesity, Graded exercise test

\section{서 론}

체중 증가는 고혈압 및 당뇨병 등 대사이상의 발생과 직접적인 관련이 있으며, 뇌졸중, 관상동맥 심장질환 및 동맥경화의 위험요인으로 인식되고 있다(Kotsis et al., 2010; Bekkers et al., 2012; Landsberg et al., 2013; Brunner et al., 2015; Chen et al., 2015). 체중과 안정 시 혈압 간에는 밀접 한 관련이 있으며, 체중이 증가할수록 고혈압 유병률은 증가하는 것으로 알려져 있다(Richards et al., 1996; Kotsis et al., 2010). 그 기전으로 비만은 나트륨 저류, 인슐린 저 항성, 심장의 형태학적 변화 및 염증반응을 유발하여 이 에 따른 혈관내피기능의 변화로 인해 고혈압이 촉진된다
(Kotsis et al., 2010). 한편, 단계적 점증부하 운동 시 혈압 상승이 클수록 고혈압 유병률은 증가하며(Lund-Johansen, 2002; Miyai et al., 2002), 안정 시 혈압보다 운동 시 혈압 반응은 심장에 가해지는 부하를 반영하므로 심혈관사건 발생을 더 잘 예측하는 지표로 보고된 바 있다(Filipovský et al., 1992). 또한 정상 혈압의 당뇨 환자에서 운동에 따른 혈압반응의 증가는 표적 기관손상 지표이며, 고혈압 환자 에서 운동 중 과도한 혈압반응은 혈관내피계 확장 기능의 손상에 의한 것으로 보고된다(Stewart et al., 2004; Ajayi et al., 2010).

혈압은 심박출량(cardiac output, $\mathrm{CO}$ )과 총 말초저항(total peripheral resistance, TPR)의 곱으로 나타내며, 심박출량은 수축기 혈압을, 총 말초저항은 이완기 혈압을 결정하는 주

*Received: April 25, 2017 / Revised: August 9, 2017 / Accepted: August 9, 2017

${ }^{\dagger}$ Corresponding author: Kyung-A Shin. Department of Clinical Laboratory Science, Shinsung University, 1 Daehak-Ro, Dangjin-Si 31801, Korea. Tel: +82-41-350-1408, Fax:+82-41-350-1355, e-mail: mobitz2@hanmail.net (C) The Korean Society for Biomedical Laboratory Sciences. All rights reserved.

(c) This is an Open Access article distributed under the terms of the Creative Commons Attribution Non-Commercial License (http://creativecommons.org/licenses/by-nc/3.0/) which permits unrestricted non-commercial use, distribution, and reproduction in any medium, provided the original work is properly cited. 
요 인자이다(Lim et al., 1996). 점증적인 운동부하에 의해 수축기 혈압은 심박출량 증가에 비례하여 상승하는 반면 총 말초저항의 감소와 혈관확장으로 인해 이완기 혈압은 변화없이 일정하게 유지된다(Lim et al., 1996). 비만인의 과 도한 체지방은 운동수행에 필요한 조직 및 호흡순환계에 과부하를 주며, 수축기 혈압과 혈관저항이 증가하여 폐기 능 및 심박출량을 저하시킨다(Sung et al., 1997; Lazarus et al., 1998; Barone et al., 2009; Ceylan et al., 2009). 또한 비만 은 교감신경계를 활성화하여 심혈관 반응에 변화를 일으 켜 운동과 같은 스트레스로 인해 지속적인 혈관수축 반응 을 유발하는 것으로 알려져 있다(Jern et al., 1992). 이와 같 이 여러 연구에서 혈압과 비만관련 요인 간의 관련성에 대해 평가하였으나, 비만과 운동 시 혈압반응을 평가한 연구는 매우 제한적이다. 이 연구는 단계적 운동부하검사 시 운동 단계별뿐만 아니라 운동 후 회복기 동안에 정상 체중군과 비교해 비만군의 혈압반응을 평가하고 혈압에 영향을 미치는 요인을 확인하여 비만인의 운동에 따른 심 혈관 위험 가능성을 알아보고자 하였다.

\section{재료 및 방법}

\section{연구 대상자 및 비만 진단}

본 연구의 대상자는 2012년 1월부터 2014년 12월까지 일개 종합병원의 건강검진센터를 통해 운동부하검사를 실 시한 20세 이상 80 세 이하 성인을 대상으로 하였다. 전체 대상자 총 196 명 중 고혈압 진단을 받았거나 고혈압 약제 를 복용 중인 사람과 결측치를 포함하는 7명을 제외한 최 종 연구 대상자는 189 명이었다. 복용 중인 약물은 자기기 입식 문진표를 통해 조사하였으며, 본 연구는 경기지역 종합병원에서 기관생명윤리위원회 승인을 받아 시행하였 다(IRB No: D-1206-012-4781). 비만 진단기준은 비만치료 지침에 따라 체질량지수가 $25 \mathrm{~kg} / \mathrm{m}^{2}$ 이상이거나 복부비만 기준인 허리둘레 남성 $90 \mathrm{~cm}$ 이상, 여성 $85 \mathrm{~cm}$ 이상일 경 우 비만군(obese, $\mathrm{N}=84$ ), 두 기준에 해당하지 않는 경우 정상 체중군(non-obese, $\mathrm{N}=105)$ 으로 분류하였다(Korean Endocrine Society, 2010).

\section{신체계측 및 운동부하검사}

DS-103M (Jenix, Seoul, Korea) 자동 신체 계측기로 신 장과 체중을 측정하였으며, 체질량지수(body mass index, $\mathrm{BMI})$ 는 체중 $(\mathrm{kg})$ 을 신장 $(\mathrm{meter})$ 의 제곱으로 나눈 값으로 계산하였다. 허리둘레는 양발 간격을 $25 \sim 30 \mathrm{~cm}$ 정도 벌
리고 서서 체중을 균등히 분배시키고, 숨을 내쉰 상태에 서 최하위 갈비뼈하부와 골반엉덩뼈능선과의 중간부위를 측정하였다. 엉덩이 둘레는 옆에서 보았을 때 엉덩이의 가 장 높은 곳을 측정하였다. 허리둘레-엉덩이 비(waist to hip ratio, WHR)는 허리둘레를 엉덩이둘레로 나누어 구하였으 며, 허리둘레-키의 비(waist to height ratio, WHtR)는 허리 둘레를 신장으로 나누어 구했다. 안정 시 혈압은 10 분 이 상 안정을 취한 후 의자에 앉은 상태에서 수은 혈압계로 측정하였으며, 10 분 간격으로 2 회 측정하여 평균값을 구하 여 기록하였다. 운동부하검사는 treadmill (Medtrack ST 55, Quinton Instrument Co., USA)을 이용하여 Bruce 프로토콜 에 따라 시행하였으며, Bruce 프로토콜은 3 분 간격으로 회 전속도와 경사도를 통해 부하량에 따라 단계(stage)를 증 가시키는 방법이다. 운동직전과 운동 중 1 분 간격으로 심 전도를 기록하였고 심박수와 혈압은 2 분 간격으로 측정하 였으며, 회복기는 1 분, 3 분, 5 분에 심전도, 심박수, 혈압을 측정하였다. 운동부하검사 중 심박수 측정 및 심전도 측 정을 위해 12채널 Quinton stress test system (Q4500, Quinton Instrument Co., USA)을 이용하였으며, 최대 심박수(220나이)의 85 90\% 이상 도달할 때까지 시행하였다. 또한 treadmill의 속도와 경사도를 이용하여 대사당량(metabolic equivalents, METs)을 구하였으며, 구체적인 공식은 다음과 같다. METs $=[($ Speed $\times 0.1)+($ Grade $/ 100 \times 1.8 \times$ Speed $)$ +3.5 ] / 3.5이다. 회복기는 운동 직후 $30 ~ 40$ 초 간 경사도 $0 \%$ 에서 속도를 $1.3 \mathrm{mph}$ 로 하여 걷고 treadmill이 완전히 멈춘 후 침대에 누워 5 분간 회복기 반응을 확인하였다. 평균동맥압(mean arterial pressure, MAP)은 혈액을 체순환 계로 밀어내는 평균압력으로 이완기 혈압 + (수축기 혈압 - 이완기 혈압) $\times 1 / 3$ 의 공식으로 계산하였다. 안정 시, 운동부하검사 중, 회복기 동안의 Delta 심박수, Delta 수축 기와 이완기 혈압, Delta 평균동맥압은 운동부하검사 전 안 정 시 값을 100 으로 하여 운동부하검사 시 각 단계별 변 화 값을 백분율로 제시하였다.

\section{혈액검사}

혈액검사는 8시간 이상 공복상태로 위팔정맥(antecubital vein)에서 채혈하였으며, 총콜레스테롤, HDL (high density lipoprotein)-콜레스테롤, LDL (low density lipoprotein)-콜레 스테롤, 중성지방, 공복혈당, 고감도 $\mathrm{C}$-반응단백질(high sensitivity C-reactive protein, hs-CRP), 요산을 TBA-200FR NEO (Toshiba, Tokyo, Japan) 생화학 자동분석기로 측정하 였다. 당화혈색소(hemoglobin Alc, HbAlc)는 고성능액체 
크로마토그래피법(high performance liquid chromatography, $\mathrm{HPLC}$ )의 원리로 Variant II (Bio Rad, CA, USA) 장비로 측 정하였다. 인슐린은 전기화학발광면역분석법(electrochemiluminescence immunoassay, ECLIA)의 원리로 Modular Analytics E170 (Roche, Mannheim, Germany) 장비로 검사하 였다.

\section{자료처리방법}

본 연구의 통계학적 분석은 SPSS Windows 21.0 (IBM, Armonk, USA) 통계 프로그램을 이용하여 기술 통계치를 산출하였다. 비만군과 정상 체중군 간의 신체구성 및 혈 액학적 변인, 운동부하검사 시 혈압반응의 차이를 알아보 기 위해 독립표본 $t$ 검증(Independent $t$-test)을 실시하였으
며, 두 집단간 성별의 차이를 알아보기 위해 카이제곱 검 정(chi-square test)을 실시하였다. 운동부하검사 중 최대 수 축기와 이완기 혈압의 변화율을 종속변수로 하여 영향을 미치는 위험요인을 알아보기 위해 성별과 연령을 보정한 후 중다회귀분석(multiple regression analysis)을 실시하였으 며, 모든 통계적 유의수준은 $P<0.05$ 로 설정하였다.

\section{결 과}

비만군과 정상 체중군 간의 신체구성 및 혈액학적 특성 의 차이

이 연구에 참여한 대상자를 비만군(Obese)과 정상 체중 군(Non-Obese)으로 분류하여 집단 간 신체구성 및 혈액학

Table 1. The body composition and hematological characteristics of subjects

\begin{tabular}{|c|c|c|c|}
\hline Variable & $\begin{array}{c}\text { Obese } \\
(\mathrm{N}=84)\end{array}$ & $\begin{array}{l}\text { Non-obese } \\
(\mathrm{N}=105)\end{array}$ & $P$-value \\
\hline Male $(\%)^{*}$ & $64(76.2)$ & $68(64.8)$ & 0.089 \\
\hline Age (years) & $49.82 \pm 9.15$ & $46.47 \pm 10.84$ & 0.025 \\
\hline Height (cm) & $166.36 \pm 9.20$ & $165.66 \pm 8.74$ & 0.593 \\
\hline Weight (kg) & $74.99 \pm 11.85$ & $60.85 \pm 8.00$ & $<0.001$ \\
\hline $\operatorname{BMI}\left(\mathrm{kg} / \mathrm{m}^{2}\right)$ & $26.96 \pm 2.51$ & $22.05 \pm 1.57$ & $<0.001$ \\
\hline Waist circumference $(\mathrm{cm})$ & $88.29 \pm 6.41$ & $76.90 \pm 6.17$ & $<0.001$ \\
\hline Hip circumference (cm) & $98.40 \pm 5.08$ & $91.59 \pm 4.36$ & $<0.001$ \\
\hline WHR $(\mathrm{cm})$ & $0.93 \pm 0.05$ & $0.85 \pm 0.06$ & $<0.001$ \\
\hline WHtR $(\mathrm{cm})$ & $0.53 \pm 0.04$ & $0.46 \pm 0.03$ & $<0.001$ \\
\hline Resting HR (bpm) & $64.13 \pm 9.43$ & $64.32 \pm 13.21$ & 0.909 \\
\hline Resting SBP (mmHg) & $118.80 \pm 14.26$ & $110.66 \pm 15.28$ & $<0.001$ \\
\hline Resting DBP (mmHg) & $77.91 \pm 9.70$ & $71.90 \pm 11.05$ & $<0.001$ \\
\hline Total cholesterol (mg/dL) & $209.39 \pm 36.02$ & $194.24 \pm 29.87$ & 0.002 \\
\hline HDL-cholesterol (mg/dL) & $50.03 \pm 11.81$ & $53.62 \pm 13.78$ & 0.059 \\
\hline LDL-cholesterol (mg/dL) & $137.25 \pm 33.40$ & $121.37 \pm 27.40$ & $<0.001$ \\
\hline Triglyceride (mg/dL) & $148.61 \pm 86.20$ & $126.33 \pm 86.86$ & 0.080 \\
\hline Fasting glucose $(\mathrm{mg} / \mathrm{dL})$ & $98.14 \pm 16.16$ & $93.26 \pm 17.89$ & 0.054 \\
\hline hs-CRP (mg/dL) & $0.28 \pm 0.76$ & $0.17 \pm 0.42$ & 0.227 \\
\hline HbAlc (\%) & $5.91 \pm 0.61$ & $5.73 \pm 0.66$ & 0.067 \\
\hline $\operatorname{Insulin}(\mu \mathrm{U} / \mathrm{mL})$ & $8.14 \pm 4.69$ & $4.91 \pm 2.63$ & $<0.001$ \\
\hline Uric acid (mg/dL) & $5.79 \pm 1.41$ & $5.23 \pm 1.40$ & 0.007 \\
\hline
\end{tabular}

Calculated by Independent $t$-test.

Values are presented as mean \pm SD.

*; Calculated by $\chi^{2}$-test. Data are presented as number $(\%)$.

Abbreviations: BMI, body mass index; WHR, waist to hip ratio; WHtR, waist to height ratio; SBP, systolic blood pressure; DBP, diastolic blood pressure; HR, heart rate; HDL, high density lipoprotein; LDL, low density lipoprotein; hs-CRP, high sensitivity C-reactive protein; HbA1c, hemoglobin A1c. 
적 특성의 차이를 비교한 결과 연령은 집단 간 차이가 있었으며, 정상 체중군보다 비만군의 연령이 높았다 $(P=$ 0.025). 신체구성을 측정하는 항목 중 체중, $\mathrm{BMI}$, 허리둘 레, 엉덩이둘레, $\mathrm{WHR}, \mathrm{WHtR}$ 은 정상 체중군보다 비만군에 서 높게 나타났다(각각 $P<0.001)$. 안정 시 수축기와 이완 기 혈압은 정상 체중군보다 비만군이 높았으나(각각 $P<$ $0.001)$, 심박수는 집단 간 차이가 없었다. 혈액학적 변인 중 총콜레스테롤 $(P=0.002), \mathrm{LDL}-$ 콜레스테롤 $(P<0.001)$, 인 슐린 $(P<0.001)$, 요산 $(P=0.007)$ 은 정상 체중군보다 비만군 에서 통계적으로 유의하게 높았다. 그러나 중성지방, 공복 혈당, hs-CRP, $\mathrm{HbAlc}$ 는 정상 체중군에 비해 비만군에서 높은 경향을 보였으나 통계적 유의성은 없었으며, HDL콜레스테롤은 정상 체중군보다 비만군에서 낮은 경향을
보였으나 통계적 유의성은 없었다(Table 1).

\section{비만군과 정상 체중군 간의 운동부하검사 중 운동능력 및 심혈관 반응의 차이}

정상 체중군과 비만군의 운동부하검사 중 심혈관 반응 의 차이를 비교한 결과 운동능력을 나타내는 운동지속시 간 $(P=0.046)$ 과 $\mathrm{METs}(P=0.015)$ 는 정상 체중군보다 비만 군이 유의하게 낮았다. 운동부하검사 전 누운 상태의 수 축기 혈압 $(P=0.040)$ 및 이완기 혈압 $(P=0.042)$, 평균동맥압 $(P=0.029)$ 은 정상 체중군보다 비만군에서 유의하게 높았 으나, 누운 상태의 심박수는 차이가 없었다. 운동부하검사 전 상태를 기준으로 운동부하검사 1 단계의 심박수, 수축 기와 이완기 혈압, 평균동맥압의 변화율은 정상 체중군과

Table 2. Comparison of the cardiovascular response during graded exercise test by obese and non-obese

\begin{tabular}{|c|c|c|c|}
\hline Variable & $\begin{array}{c}\text { Obese } \\
(\mathrm{N}=84)\end{array}$ & $\begin{array}{l}\text { Non-obese } \\
(\mathrm{N}=105)\end{array}$ & $P$-value \\
\hline Exercise duration (min) & $9.34 \pm 1.88$ & $9.87 \pm 1.73$ & 0.046 \\
\hline Exercise capacity (METs) & $11.16 \pm 2.37$ & $11.94 \pm 1.84$ & 0.015 \\
\hline Supine HR (bpm) & $61.94 \pm 8.77$ & $63.76 \pm 11.76$ & 0.239 \\
\hline Supine SBP (mmHg) & $122.64 \pm 14.11$ & $118.02 \pm 16.02$ & 0.040 \\
\hline Supine DBP (mmHg) & $77.53 \pm 11.02$ & $74.05 \pm 12.03$ & 0.042 \\
\hline Supine MAP (mmHg) & $92.57 \pm 11.13$ & $88.71 \pm 12.61$ & 0.029 \\
\hline$\Delta$ stage 1 HR $(\%)$ & $168.48 \pm 24.74$ & $166.39 \pm 20.22$ & 0.524 \\
\hline$\Delta$ stage $1 \mathrm{SBP}(\%)$ & $111.93 \pm 13.41$ & $111.99 \pm 11.49$ & 0.973 \\
\hline$\Delta$ stage 1 DBP $(\%)$ & $101.41 \pm 12.21$ & $103.66 \pm 14.86$ & 0.266 \\
\hline$\Delta$ stage 1 MAP $(\%)$ & $105.99 \pm 9.89$ & $107.21 \pm 11.40$ & 0.439 \\
\hline$\Delta$ stage 2 HR $(\%)$ & $193.60 \pm 27.85$ & $196.99 \pm 25.35$ & 0.385 \\
\hline$\Delta$ stage $2 \mathrm{SBP}(\%)$ & $121.11 \pm 15.08$ & $120.54 \pm 14.17$ & 0.790 \\
\hline$\Delta$ stage 2 DBP $(\%)$ & $102.13 \pm 11.31$ & $102.74 \pm 14.57$ & 0.753 \\
\hline$\Delta$ stage 2 MAP $(\%)$ & $110.43 \pm 10.38$ & $110.48 \pm 11.77$ & 0.974 \\
\hline$\Delta$ stage 3 HR $(\%)$ & $227.47 \pm 32.67$ & $232.59 \pm 33.36$ & 0.301 \\
\hline$\Delta$ stage $3 \mathrm{SBP}(\%)$ & $131.96 \pm 16.14$ & $129.79 \pm 16.49$ & 0.374 \\
\hline$\Delta$ stage 3 DBP $(\%)$ & $103.64 \pm 12.26$ & $105.65 \pm 15.41$ & 0.341 \\
\hline$\Delta$ stage 3 MAP $(\%)$ & $111.28 \pm 11.88$ & $112.82 \pm 12.64$ & 0.403 \\
\hline$\Delta$ maximum HR $(\%)$ & $256.43 \pm 36.16$ & $264.14 \pm 45.62$ & 0.208 \\
\hline$\Delta$ maximum SBP $(\%)$ & $139.89 \pm 16.04$ & $138.65 \pm 17.64$ & 0.621 \\
\hline$\Delta$ maximum DBP $(\%)$ & $106.13 \pm 11.80$ & $109.94 \pm 15.38$ & 0.063 \\
\hline$\Delta$ maximum MAP $(\%)$ & $120.94 \pm 11.45$ & $122.51 \pm 13.81$ & 0.405 \\
\hline
\end{tabular}

Calculated by Independent $t$-test.

Values are presented as mean \pm SD.

Abbreviations: METs, metabolic equivalents; HR, heart rate; SBP, systolic blood pressure; DBP, diastolic blood pressure; MAP, mean atrial pressure; $\Delta$, change values. 
Table 3. Comparison of the cardiovascular response during graded exercise test recovery by obese and non-obese

\begin{tabular}{|c|c|c|c|}
\hline Variable & $\begin{array}{c}\text { Obese } \\
(\mathrm{N}=84)\end{array}$ & $\begin{array}{l}\text { Non-obese } \\
(\mathrm{N}=105)\end{array}$ & $P$-value \\
\hline$\Delta$ recovery $1 \min \mathrm{HR}(\%)$ & $204.18 \pm 29.67$ & $208.75 \pm 37.60$ & 0.364 \\
\hline$\Delta$ recovery 1 min SBP $(\%)$ & $128.65 \pm 19.60$ & $120.51 \pm 19.93$ & 0.020 \\
\hline$\Delta$ recovery 1 min DBP $(\%)$ & $101.02 \pm 17.43$ & $103.54 \pm 18.32$ & 0.420 \\
\hline$\Delta$ recovery 1 min $\mathrm{MAP}(\%)$ & $113.23 \pm 16.20$ & $110.90 \pm 16.31$ & 0.413 \\
\hline$\Delta$ recovery $3 \min \mathrm{HR}(\%)$ & $145.91 \pm 19.30$ & $150.55 \pm 24.03$ & 0.152 \\
\hline$\Delta$ recovery $3 \min \mathrm{SBP}(\%)$ & $124.24 \pm 15.05$ & $120.64 \pm 15.06$ & 0.115 \\
\hline$\Delta$ recovery $3 \min \mathrm{DBP}(\%)$ & $101.95 \pm 11.58$ & $103.71 \pm 11.86$ & 0.322 \\
\hline$\Delta$ recovery $3 \min \mathrm{MAP}(\%)$ & $111.72 \pm 11.47$ & $111.06 \pm 11.13$ & 0.701 \\
\hline$\Delta$ recovery $5 \min \mathrm{HR}(\%)$ & $137.91 \pm 15.50$ & $139.99 \pm 20.10$ & 0.425 \\
\hline$\Delta$ recovery $5 \min \mathrm{SBP}(\%)$ & $109.22 \pm 11.18$ & $107.62 \pm 10.68$ & 0.323 \\
\hline$\Delta$ recovery 5 min DBP (\%) & $101.06 \pm 11.60$ & $102.13 \pm 10.66$ & 0.515 \\
\hline$\Delta$ recovery $5 \min \mathrm{MAP}(\%)$ & $104.53 \pm 9.82$ & $104.43 \pm 8.97$ & 0.941 \\
\hline
\end{tabular}

Calculated by Independent $t$-test.

Values are presented as mean \pm SD.

Abbreviations: HR, heart rate; SBP, systolic blood pressure; DBP, diastolic blood pressure; MAP, mean atrial pressure; $\Delta$, change values.

비만군 간의 차이가 없었다. 운동부하검사 2단계에서 심 박수, 수축기와 이완기 혈압, 평균동맥압의 변화율의 집단 간 차이가 없었으며, 운동부하검사 3단계에서의 심박수, 수축기와 이완기 혈압, 평균동맥압의 변화율에는 집단 간 차이가 없었다. 또한 최대 운동부하검사 시 심박수, 수축 기와 이완기 혈압, 평균동맥압의 변화율은 정상 체중군과 비만군 간에 차이가 없었다(Table 2).

\section{비만군과 정상 체중군 간의 운동부하검사 회복기 동안 심혈관 반응의 차이}

운동부하검사 회복기 동안의 집단간 심혈관 반응의 차 이를 비교한 결과 운동부하검사 후 회복기 1 분대의 심박 수, 이완기 혈압, 평균동맥압의 변화율은 정상 체중군과 비만군 간에 차이가 없었으나, 수축기 혈압의 변화율은 정 상 체중군보다 비만군에서 크게 나타났다 $(P=0.020)$. 운동 부하검사 후 회복기 3 분대의 심박수, 수축기와 이완기 혈 압, 평균동맥압의 변화율은 집단 간 차이가 없었다. 또한 회복기 5 분대의 심박수, 수축기와 이완기 혈압, 평균동맥 압의 변화율은 집단 간 차이가 없는 것으로 나타났다 (Table 3).

\section{최대 수축기와 이완기 혈압 변화율에 영향을 미치는 위 험요인}

연령과 성별을 보정한 후 최대 수축기와 이완기 혈압의 변화율에 영향을 미치는 위험요인을 확인한 결과 허리둘 레 $(P=0.046)$ 와 엉덩이둘레 $(P=0.008)$ 는 최대 수축기 혈압 변화율에 영향을 미치는 위험요인으로 나타났다(Table 4).

\section{고 찰}

비만은 잠재적으로 교정 가능한 심혈관질환의 중요한 결정인자로 체중조절을 통한 비만관리에 관심이 고조되고 있다(Brunner et al., 2015). 여러 연구에서 혈압과 비만지표 간의 연관성을 평가하였으나(Kotsis et al., 2010; Landsberg et al., 2013), 비만과 운동 시 혈압반응을 평가한 연구는 매 우 제한적이다. 이 연구는 성인 비만인을 대상으로 단계 적 운동부하검사 시 나타나는 혈압반응을 평가하고자 하 였다. 그 결과 비만군은 짧은 운동시간과 낮은 운동능력 에도 불구하고 운동 단계별 혈압반응 변화율은 정상 체중 군과 차이가 없었으며, 비만군에서 회복기 1 분대에 수축 기 혈압 회복율이 더디게 나타났다. 또한 허리둘레와 엉 덩이둘레는 운동부하검사 시 최대 수축기 혈압 상승률에 영향을 미치는 요인으로 나타났다. 
Table 4. Association between systolic/diastolic blood pressure and the cardiovascular risk factors in non-obese group

\begin{tabular}{|c|c|c|c|c|c|c|c|c|}
\hline \multirow{2}{*}{ Variable } & \multicolumn{4}{|c|}{$\Delta$ maximum SBP $(\%)$} & \multicolumn{4}{|c|}{$\Delta$ maximum DBP $(\%)$} \\
\hline & $\beta$ & $\mathrm{SE}$ & $P$ & VIF & $\beta$ & SE & $P$ & VIF \\
\hline BMI $\left(\mathrm{kg} / \mathrm{m}^{2}\right)$ & -0.052 & 0.614 & 0.647 & 2.497 & -0.090 & 0.503 & 0.423 & 2.497 \\
\hline Waist circumference $(\mathrm{cm})$ & -0.283 & 0.284 & 0.046 & 3.824 & -0.230 & 0.233 & 0.101 & 3.824 \\
\hline Hip circumference $(\mathrm{cm})$ & 0.349 & 0.378 & 0.008 & 3.215 & 0.145 & 0.309 & 0.257 & 3.215 \\
\hline Triglyceride (mg/dL) & 0.061 & 0.022 & 0.592 & 1.399 & 0.132 & 0.041 & 0.101 & 1.259 \\
\hline HDL-cholesterol (mg/dL) & -0.181 & 0.132 & 0.082 & 1.330 & -0.046 & 0.122 & 0.675 & 1.330 \\
\hline LDL-cholesterol (mg/dL) & 0.150 & 0.067 & 0.174 & 1.294 & 0.110 & 0.062 & 0.312 & 1.294 \\
\hline \multirow[t]{2}{*}{ Fasting glucose (mg/dL) } & -0.043 & 0.093 & 0.673 & 1.111 & -0.172 & 0.085 & 0.089 & 1.111 \\
\hline & \multicolumn{4}{|c|}{$F=4.478^{* *}, R^{2}=0.166, \operatorname{Adj} R^{2}=0.147$} & \multicolumn{4}{|c|}{$F=4.101^{* *}, R^{2}=0.170$, Adj $R^{2}=0.131$} \\
\hline
\end{tabular}

Calculated by multivariable linear regression analysis adjusted for age and gender.

**; $P<0.01$.

Abbreviations: $\Delta$, change values; SBP, systolic blood pressure; DBP, diastolic blood pressure; BMI, body mass index; HDL, high density lipoprotein; LDL, low density lipoprotein.

비만은 고혈압, 당뇨병, 고지혈증과 인슐린 저항성 및 동맥경화의 위험을 증가시켜 심혈관질환 이환율에 영향을 미치며, 이와 관련된 질환에 의한 사망률을 증가시키는 것 으로 보고된다(Kim et al., 2005; Park et al., 2005; Després et al., 2008). 체중과 안정 시 혈압 간에 관련이 있으며, 체중 증가에 비례하여 고혈압 유병률이 증가하는 것으로 알려 져 있다(Richards et al., 1996; Kotsis et al., 2010). 그 기전으 로 비만에 의한 내분비계의 대사 조절장애, 교감신경계 활성에 의한 혈관수축 반응, 좌심실 질량 증가 및 좌심실 비대와 같은 심장구조의 변형으로 인한 혈역학적 변화에 기인하는 것으로 알려진다(Jern et al., 1992; Choi et al., 2010; Dibeklioglu et al., 2017). 고혈압에 대한 선행연구들은 대 부분 안정 시 혈압을 기준으로 평가되었으며, 이는 운동 시 심장에 가해지는 부하에 의한 혈압 변화를 충분히 반 영할 수 없었다(Kim et al., 2001). 또한 안정 시 수축기 혈 압 상승보다 운동 시 수축기 혈압의 상승 정도가 심혈관 계질환의 강력한 위험인자이며(Filipovský et al., 1992), 안정 시 혈압이 정상이더라도 운동 시 수축기 혈압의 상승폭이 클수록 향후 안정 시에도 고혈압으로 이환될 가능성이 높 음을 알 수 있다(Weiss et al., 2010).

본 연구결과에서 비만군은 운동부하검사를 일찍 중단하 여 짧은 운동시간과 낮은 운동능력에도 불구하고 정상 체 중군과 비교해 운동 단계별 혈압반응의 변화율에는 차이 가 없었다. 이는 비만군에서 혈압이 더 상승할 조건을 갖 칬음에도 불구하고 운동능력이 낮았기 때문에 운동 단계 별 혈압반응 변화율에 차이가 없었던 것으로 생각되며,
동일한 체력이라면 혈압반응에 차이가 있을 것으로 예상 된다. 비만은 나트륨 저류, 인슐린 저항성 및 염증반응과 관련이 있어 혈관내피기능의 변화로 고혈압을 촉진시킬 수 있다(Kotsis et al., 2010). 본 연구결과를 통해 정상 체중 군과 비교해 비만군에서 짧은 운동시간에도 동일한 혈압 상승률을 보이는 것을 확인하였으며, 정상 체중군보다 비 만군에서 회복기 1 분대의 수축기 혈압이 더디게 회복되는 반응을 보였다. 운동 후 회복기 동안 수축기 혈압의 회복 이 지연되는 반응은 관상동맥질환의 가능성을 높인다고 알려져 있어 비만군에서 안정 시 혈압뿐만 아니라 운동 중 또는 회복기 동안 주기적으로 혈압을 측정하는 것이 요구된다(McHam et al., 1999).

운동부하검사 중 나타나는 높은 혈압반응은 혈관벽의 저항을 증가시킴으로 혈관내피세포의 손상을 유발하며, 심근의 산소소모량 및 혈관벽 두께의 증가를 통해 동맥경 화를 촉진시켜 심혈관질환을 유도한다고 보고된다(Allison et al., 1999). 체중 감소는 인슐린 민감성과 그에 따른 교 감신경계의 적절한 조절, 순환 혈액량 감소로 인한 심박 출량 감소, 혈중 전해질 변화에 따른 혈관저항 감소 기전 에 의해 혈압의 감소가 나타난다(Reisin, 1997; Stone and Kushner, 2000). 비만인이라 할지라도 모두 고혈압으로 이 환되지는 않지만, 체중과 체지방량은 혈압 증가와 높은 상관관계를 보인다(Becker Mde et al., 2007). Kim (2011)은 $\mathrm{BMI}$ 가 증가함에 따라 혈압이 상승하며, BMI, 체지방률, WHR과 같은 비만지표 중 혈압과 높은 상관성을 보이는 지표는 BMI라 보고하였다. 또한 복부비만과 고혈압 및 
당뇨병 발병은 관련이 있으며, WHR과 $\mathrm{BMI}$ 는 운동 중 수축기 혈압과 상관성을 보인다고 보고된다(Folsom et al., 1990; Kim, 2006). 본 연구에서 허리둘레와 엉덩이둘레가 운동부하검사 시 최대 수축기 혈압 상승률에 영향을 미 치는 위험요인으로 나타나 비만지표가 혈압 상승과 관련 이 있다는 선행연구와 유사한 결과를 보였으며, 비만지표 를 개선하여 심혈관계질환의 발병 위험을 낮추려는 시도 가 이루어져야 할 것이다(Adams et al., 2006). 또한 비만인 에서 운동부하검사를 통해 사전에 혈압 상승반응 및 심혈 관 변화를 관찰함으로써 운동 중 나타날 수 있는 심혈관 계 위험을 미리 예측하는 것이 필요하리라 생각된다(Kim, 2006).

본 연구는 비만에 영향을 미치는 식이요법, 신체활동 수 준과 흡연여부에 대한 정보가 배제되었다는 제한점이 있 다. 또한 일개 종합병원에서 건강검진을 시행한 성인을 대상으로 하였으므로 결과를 다른 대상자에게 확대 해석 하는데 제한이 있으며, 후향적 연구로 결과의 인과관계를 밝힐 수 없었다. 향후 임상경과를 비교하여 비만군에서 고 혈압으로 발전할 가능성에 대한 연구와 체중조절에 의해 운동부하검사 시 혈압반응에 어떠한 변화가 나타나는지에 대한 전향적 연구가 요구된다.

\section{CONFLICT OF INTEREST}

The authors have no conflicts of interest to disclose.

\section{REFERENCES}

Adams KF, Schatzkin A, Harris TB, Kipnis V, Mouw T, BallardBarbash R, Hollenbeck A, Leitzmann MF. Overweight, obesity, and mortality in a large prospective cohort of persons 50 to 71 years old. New England Journal of Medicine. 2006. 355: 763-778.

Ajayi EA, Balogun MO, Akintomide OA, Adebayo RA, Ajayi OE, Ikem RT, Ogunyemi SA, Oyedeji AT. Blood pressure response to an exercise treadmill test, and echocardiographic left ventricular geometry in Nigerian normotensive diabetics. Cardiovascular Journal of South Africa. 2010. 21: 93-96.

Allison TG, Cordeiro MA, Miller TD, Daida H, Squires RW, Gau GT. Prognostic significance of exercise-induced systemic hypertension in healthy subjects. American Journal of Cardiology. 1999. 83: 371-375.

Barone BB, Wang NY, Bacher AC, Stewart KJ. Decreased exercise blood pressure in older adults after exercise training: contri- butions of increased fitness and decreased fatness. British Journal of Sports Medicine. 2009. 43: 52-56.

Becker Mde M, Barbosa e Silva O, Moreira IE, Victor EG. Arterial blood pressure in adolescents during exercise stress testing. Arquivos Brasileiros de Cardiologia. 2007. 88: 329-333.

Bekkers MB, Brunekreef B, Koppelman GH, Kerkhof M, de Jongste JC, Smit HA, Wijga AH. BMI and waist circumference; cross-sectional and prospective associations with blood pressure and cholesterol in 12-year-olds. Public Library of Science One. 2012. 7: e51801.

Brunner EJ, Shipley MJ, Ahmadi-Abhari S, Tabak AG, McEniery CM, Wilkinson IB, Marmot MG, Singh-Manoux A, Kivimaki M. Adiposity, obesity, and arterial aging: longitudinal study of aortic stiffness in the Whitehall II cohort. Hypertension. 2015. 66: 294-300.

Ceylan E, Cömlekçi A, Akkoçlu A, Ceylan C, Itil O, Ergör G, Yeşil $\mathrm{S}$. The effects of body fat distribution on pulmonary function tests in the overweight and obese. Southern Medical Journal. 2009. 102: 30-35.

Chen X, Du H, Zhang J, Chen X, Luo G, Que X, Zhang N, Bian Z, Guo Y, Li L, Chen Z, Wu X. Adiposity and blood pressure among 55000 relatively lean rural adults in southwest of China. Journal of Human Hypertension. 2015. 29: 522-529.

Choi HM, Chun JM, Park CH, Yoo H, Nho HS, Kim JK. The cardiovascular response in exercise intensity with obese middle aged women. The Korean Journal of Growth and Development. 2010. 18: 187-194.

Després JP, Lemieux I, Bergeron J, Pibarot P, Mathieu P, Larose E, Rodés-Cabau J, Bertrand OF, Poirier P. Abdominal obesity and the metabolic syndrome: contribution to global cardiometabolic risk. Arteriosclerosis, Thrombosis, and Vascular Biology. 2008. 28: 1039-1049.

Dibeklioglu SE, Çevik BŞ, Acar B, Özçakar ZB, Uncu N, Kara N, Çaycı Ş, Çakar N. The association between obesity, hypertension and left ventricular mass in adolescents. Journal of Pediatric Endocrinology and Metabolism. 2017. 30: 167-174.

Filipovský J, Ducimetière P, Safar ME. Prognostic significance of exercise blood pressure and heart rate in middle-aged men. Hypertension. 1992. 20: 333-339.

Folsom AR, Prineas RJ, Kaye SA, Munger RG. Incidence of hypertension and stroke in relation to body fat distribution and other risk factors in older women. Stroke. 1990. 21: 701-716.

Jern S, Bergbrant A, Björntorp P, Hansson L. Relation of central hemodynamics to obesity and body fat distribution. Hypertension. 1992. 19: 520-527. 
Kim CG. Effect of health behavior and obesity indices on blood pressure in 20s man. The Journal of the Korea Contents Association. 2011. 11: 231-238.

Kim HJ, Lee WS, Song YB, Ahn JH, Lee SY, Kim SW, Kim TH, Ryu WS. Relationship between exercise-induced blood pressure response and left ventricular hypertrophy in patients with hypertension. Korean Circulation Journal. 2001. 31: 809 $-814$.

Kim JY, Shin HW, Jeong IK, Cho SW, Min SJ, Lee SJ, Park CY, Oh KW, Hong EG, Kim HK, Kim DM, Yu JM, Ihm SH, Choi MG, Yoo HJ, Park SW. The relationship of adiponectin, leptin and ghrelin to insulin resistance and cardiovascular risk factors in human obesity. Korean Journal of Medicine. 2005. 69: 631-641.

Kim YJ. Left ventricular hypertrophy, body composition, and maximal systolic blood pressure during exercise in exerciseinduced hypertension patients accompanied by coronary artery disease. Journal of Sport and Leisure Studies. 2006. 28: 269 -279 .

Korean Endocrine Society, Korean society for the Study of Obesity. Management of Obesity, 2010 Recommendation. Endocrinology and Metabolism. 2010. 25: 301-304.

Kotsis V, Stabouli S, Papakatsika S, Rizos Z, Parati G. Mechanisms of obesity-induced hypertension. Hypertension Research. 2010. 33: 386-393.

Landsberg L, Aronne LJ, Beilin LJ, Burke V, Igel LI, Lloyd-Jones D, Sowers J. Obesity-related hypertension: pathogenesis, cardiovascular risk, and treatment: a position paper of The Obesity Society and the American Society of Hypertension. Journal of Clinical Hypertension. 2013. 15: 14-33.

Lazarus R, Gore CJ, Booth M, Owen N. Effects of body composition and fat distribution on ventilatory function in adults. American Journal of Clinical Nutrition. 1998. 68: 35-41.

Lim PO, MacFadyen RJ, Clarkson PB, MacDonald TM. Impaired exercise tolerance in hypertensive patients. Annals of Internal Medicine. 1996. 124: 41-55.

Lund-Johansen P. Blood pressure response during exercise as a prognostic factor. Journal of Hypertension. 2002. 20: 1473
$-1475$.

McHam SA, Marwick TH, Pashkow FJ, Lauer MS. Delayed systolic blood pressure recovery after graded exercise: an independent correlate of angiographic coronary disease. Journal of the American College of Cardiology. 1999. 34: 754-759.

Miyai N, Arita M, Miyashita K, Morioka I, Shiraishi T, Nishio I. Blood pressure response to heart rate during exercise test and risk of future hypertension. Hypertension. 2002. 39: 761-766.

Park SB, Yun KW, Cho SJ. Expression of adipokines in obese adult and correlation with psychosocial factors. Korean Journal of Obesity. 2005. 14: 82-93.

Reisin E. Nonpharmacologic approaches to hypertension. Weight, sodium, alcohol, exercise, and tobacco considerations. Medical Clinics of North America. 1997. 81: 1289-1303.

Richards RJ, Thakur V, Reisin E. Obesity-related hypertension: its physiological basis and pharmacological approaches to its treatment. Journal of Human Hypertension. 1996. 10: S59-64.

Stewart KJ, Sung J, Silber HA, Fleg JL, Kelemen MD, Turner KL, Bacher AC, Dobrosielski DA, DeRegis JR, Shapiro EP, Ouyang P. Exaggerated exercise blood pressure is related to impaired endothelial vasodilator function. American Journal of Hypertension. 2004. 17: 314-320.

Stone NJ, Kushner R. Effects of dietary modification and treatment of obesity. Emphasis on improving vascular outcomes. Medical Clinics of North America. 2000. 84: 95-122.

Sung BH, Wilson MF, Izzo JL Jr, Ramirez L, Dandona P. Moderately obese, insulin-resistant women exhibit abnormal vascular reactivity to stress. Hypertension. 1997. 30: 848-853.

Weiss SA, Blumenthal RS, Sharrett AR, Redberg RF, Mora S. Exercise blood pressure and future cardiovascular death in asymptomatic individuals. Circulation. 2010. 121: 2109-2116.

https://doi.org/10.15616/BSL.2017.23.3.215

Cite this article as: Shin KA. The Blood Pressure Response during Graded Exercise Test in Obese Adults. Biomedical Science Letters. 2017. 23: 215-222. 